\title{
PENGARUH KERAPATAN LAMUN Thalassia hemprichii TERHADAP KELIMPAHAN BAKTERI HETEROTROF DI PANTAI PRAWEAN, JEPARA
}

\author{
Influence of Seagrass Thalassia hemprichii Density on the Abundance of Heterotrophic Bacteria at Prawean Beach, \\ Jepara \\ Isnaini Dian Yunita, Niniek Widyorini*), dan Supriharyono
}

Program Studi Manajemen Sumberdaya Perairan, Departemen Sumberdaya Akuatik

Fakultas Perikanan dan Ilmu Kelautan, Universitas Diponegoro

J1. Prof. Soedarto, SH, Tembalang, Semarang, Jawa Tengah - 50275, Telp/Fax. +6224 7474698

Email : isnainidian28@gmail.com

\begin{abstract}
ABSTRAK
Ekosistem lamun merupakan salah satu ekosistem yang memiliki kompleksitas dan keanekaragaman hayati yang tinggi. Padang lamun merupakan hamparan vegetasi lamun yang menutupi suatu kawasan pesisir. Selain memiliki fungsi ekonomi, lamun juga memiliki fungsi ekologis yakni berperan penting sebagai pendaur zat hara oleh mikroorganime yaitu bakteri. Penelitian ini bertujuan untuk mengetahui kerapatan lamun, kelimpahan bakteri heterotrof yang berasosiasi dengan lamun serta pengaruh kerapatan lamun dengan kelimpahan bakteri heterotrof di Pantai Prawean, Jepara. Metode yang digunakan yakni deskriptif eksplanatif dengan pengambilan sampel secara purposive dan dianalisis dengan IBM SPSS Statistic 22. Jenis lamun yang ditemukan di Pantai Prawean ada 5 (lima): Enhalus acoroides, Thalassia hemprichii, Cymodocea rotundata, Halodule uninervis dan Halodule pinifolia. Kerapatan tertinggi didapat dari jenis Thalassia hemprichii sebesar $78 \mathrm{Ind} / \mathrm{m}^{2}$ dan terendah adalah Enhalus acoroides $10 \mathrm{Ind} / \mathrm{m}^{2} \mathrm{dan}$ kelimpahan bakteri heterotrof tertinggi diperoleh dari tingkat kerapatan rapat di stasiun 3 yakni 29,4x10 ${ }^{8} \mathrm{Upk} / \mathrm{ml}$ dan

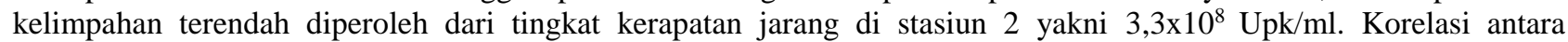
kerapatan lamun dengan kelimpahan bakteri heterotrof tinggi atau kuat yakni 0,896 dan korelasi ini dinyatakan sangat signifikan terbukti nilai sig. 0,001 dengan tingkat kesalahan 0,1\%. Artinya bertambahnya kerapatan lamun dapat meningkatkan pula kelimpahan bakteri heterotrof.
\end{abstract}

Kata Kunci :Ekosistem lamun; Bakteri Heterotrof; Pantai Prawean, Jepara

\section{ABSTRACT}

Seagrass ecosystem is one ecosytems that has high complexity and biodiversity. Seagrass beds are a stretch of seagrass vegetation that covers a coastal area. Beside its economic function, seagrass also have ecological function that play an important role of nutrient cycle for microorganism its bacteria. This study aims to determine the density of seagrass, the abundance of heterothropic bacteria and influence of seagrass density with abundance of heterotrophic bacteria at Prawean beach, Jepara. The method used in this study is descriptive explanative with purposive sampling and the data analyzed by IBM SPSS Statistic 22. There are 5 (five) species of seagrass that can be found in Prawean beach: Enhalus acoroides, Thalassia hemprichii, Cymodocea rotundata, Halodule uninervis and Halodule pinifolia. The highest density obtained from Thalassia hemprichii species is 78 sprouts of seagrass $/ \mathrm{m}^{2}$ and the lowest density obtained from Enhalus acoroides is 10 obtained from seagrass density at station 3 its value $29,4 \times 10^{8} \mathrm{Cfu} / \mathrm{ml}$ and the

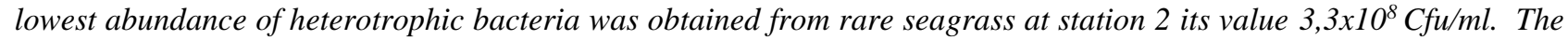
corelation between seagrass density with abundance heterotrophic bacteria is high or strong that has value 0,846 and this correlation is very significantly proven has sig value 0,001 with error rate 0,1\%, it can be conclude that increase of seagrass density can also increase the abundance of heterotrophic bacteria.

Keywords : Seagrass ecosystem; Heterotrophic bacteria; Prawean Beach, Jepara *) Penulis Penanggungjawab

\section{PENDAHULUAN}

Ekosistem padang lamun merupakan salah satu ekosistem yang memiliki kompleksitas dan keanekaragaman hayati yang tinggi. Padang lamun merupakan hamparan vegetasi lamun yang menutupi suatu kawasan pesisir. Pembangunan di pesisir yang tidak berwawasan lingkungan berdampak pada penurunan kualitas ekosistem padang lamun yang akhirnya dikhawatirkan dapat menurunkan pendapatan nelayan sebagai bentuk fungsi lanjut dari kerusakan alam, (Febriyantoro et al., 2013).

Lamun (Seagrass) merupakan satu-satunya tumbuhan yang memiliki rhizoma, daun dan akar sejati yang hidup terendam di dalam laut, (Prita et al., 2014). Selain memiliki fungsi secara ekonomi lamun juga memiliki fungsi ekologis diantapp[[nya sebagai vegetasi yang memiliki peranan penting sebagai produsen primer, daerah untuk mencari makan (feeding ground), pemijahan (spawning), pengasuhan (nursery), habitat bagi organisme lain yang berasosiasi dengannya, penstabil substrat, penahan arus dan gelombang sebelum mencapai ekosistem terumbu karang, penyerap 
$\mathrm{CO}_{2}$, perangkap sedimen dan nutrien (nutrient trap), serta berperan penting sebagai pendaur zat hara oleh mikroorganime yaitu bakteri, salah satu bakteri yang berperan sebagai dekomposer pada ekosistem lamun adalah bakteri heterotrof. Organisme perombak seperti bakteri heterotrof memanfaatkan sisa organisme yang telah mati untuk diurai menjadi unsur-unsur yang dikembalikan ke dalam tanah dan atmosfer sebagai hara yang dapat digunakan kembali oleh tanaman (Aminulloh, 2011). Sampai saat ini informasi mengenai populasi bakteri heterotrof pada ekosistem lamun masih minim, oleh karena itu perlu pengkajian secara biologi untuk mengetahui estimasi total bakteri heterotrof serta hubungannya dengan kerapatan lamun, sehingga dapat diketahui seberapa besar asosiasi bakteri heterotrof pada daun lamun. Tujuan dari penelitian ini adalah mengkaji kerapatan lamun, megkaji kelimpahan bakteri heterotrof serta untuk mengetahui pengaruh kerapatan lamun terhadap kelimpahan bakteri heterotrof di Pantai Prawean, Jepara.

\section{MATERI DAN METODE}

Penelitian dilaksanakan pada bulan Mei - Agustus 2018 di Pantai Prawean, Jepara sedangkan perhitungan total kelimpahan bakteri heterotrof dilakukan pada Laboratorium Manajemen Kesehatan Hewan Akuatik (MKHA) dan untuk parameter pendukung kualitas air dilakukan di Laboratorium Pengelolaan Sumberdaya Ikan dan Lingkungan FPIK UNDIP, Semarang.

Materi yang digunakan pada penelitian adalah daun lamun jenis Thalassia hemprichii dan sampel air serta sedimen dari padang lamun. Metode yang digunakan adalah metode deskriptif eksplanatif dengan pengambilan data secara purposive sampling. Penentuan lokasi sampling dilaksanakan berdasarkan observasi dan survei pendahuluan dengan mencari komunitas lamun yang didalamnya terdapat jenis Thalassia hemprichii kemudian ditandai dengan GPS untuk mengetahui koordinat lokasi pengambilan sampel kemudian menentukan 3 stasiun berdasarkan kerapatan rapat, sedang dan jarang. Pada masing-masing stasiun terdapat 3 titik pengukuran parameter fisika kimia dan pengambilan sampel daun lamun untuk uji bakteri heterotrof. Parameter kualitas air yang diukur meliputi kedalaman, temperatur udara, DO, Salinitas, pH, Nitrat dan Fosfat, serta dilakukan pula pengukuran tekstur sedimen.

Metode dalam uji penanaman bakteri heterotrof adalah sebagai berikut :

\section{Pembuatan Media TGY dan Larutan Trisalt}

Media yang diguanakan dalam penanaman bakteri heterotrof yakni media TGY (Triptone Glucose Yeast), dengan komposisi Tripton (5 gram), Glucose (1 gram), Yeast (2,5 gram) dan Bacto agar (15 gram), (Ariyanti et al., 2016). Setelah masing-masing media ditimbang selanjutnya menuangkan media kedalam erlenmeyer dan menambahkan aquadest $1000 \mathrm{ml}$. Memasukkan magnetic stearer ke dalam botol, menutup mulut botol dengan aluminium foil, kemudian memanaskan media diatas hot plate pada temperatur $400^{\circ} \mathrm{C}$ hingga mendidih. Sedangkan komposisi untuk pembuatan Trisalt $1000 \mathrm{ml}$ antara lain menimbang $0,75 \mathrm{gr} \mathrm{KCl} ; 6,94 \mathrm{gr} \mathrm{MgSO}_{4}$ dan 23,4 gr $\mathrm{NaCl}$ kemudian menuangkan reagen yang sudah ditimbang kedalam erlenmeyer dengan menambahkan aquadest sebanyak $1000 \mathrm{ml}$.

\section{Sterilisasi Alat dan Bahan}

Sterilisasi yang digunakan yakni sterilisasi menggunakan autoklaf, oven dan sterilisasi dengan pemijaran api langsung (Bunsen). Sterilisasi media pada autoklaf menggunakan suhu $121^{\circ} \mathrm{C}$ dan tekanan $15 \mathrm{lb} / \mathrm{in} 2(\mathrm{SI}=103,4 \mathrm{Kpa})$. Alasan digunakan suhu $121^{\circ} \mathrm{C}$ atau $249,8^{\circ} \mathrm{F}$ adalah karena air mendidih pada suhu tersebut jika digunakan tekanan 15 psi. Semua bentuk kehidupan akan mati jika didihkan pada suhu $121^{\circ} \mathrm{C}$ dan tekanan 15 psi (Hafsan et al., 2015).

\section{Penumbukan Sampel Daun Lamun}

Menimbang daun lamun Thalassia hemprichii sebanyak 0,5 gr diatas aluminium foil steril, membilas daun dengan larutan trisalt steril kemudian memotong daun kecil-kecil dan menumbuknya dengan mortar dengan bantuan larutan trisalt sebanyak $2 \mathrm{ml}$ sebagai campuran.

\section{Pengenceran Air Sampel}

Pengenceran yang dilakukan pada penelitian yakni pengenceran $\left(10^{-3}\right)$. Metode pengenceran dengan menuangkan aquadest steril sebanyak $9 \mathrm{ml}$ kedalam masing-masing tabung reaksi, kemudian diambil $1 \mathrm{ml}$ untuk dituangkan kedalam tabung reaksi pengenceran berikutnya, kemudian melakukan homogenisasi dengan vortex mixer seterusnya sampai pengenceran terakhir.

\section{Penanaman Bakteri}

Metode yang digunakan pada pengujian bakteri heterotrof yakni dengan metode sebar (spread plate), yakni media dituangkan ketika masih cair dalam cawan pettri kurang lebih sebanyak $25 \mathrm{ml}$, di dalam Laminar Air Flow untuk mengurangi kemungkinan kontaminasi. Setelah media yang dituangkan menjadi padat, selanjutnyamenuangkankan larutan sampel daun lamun yang sudah dihaluskan diatas media padat TGY. Penanaman bakteri dilakukan pada setiap tingkat pengenceran menggunakan pipet kedalam pettri dish, dan menginkubasi selama 1x24 jam didalam inkubator.

\section{Perhitungan Total Bakteri Heterotrof}

Total bakteri heterotrof dihitung manual dengan bantuan spidol untuk menandai bakteri yang tumbuh sehingga mengurangi kemungkinan pengulangan dalam perhitungan. perhitungan didasarkan dengan rumus :

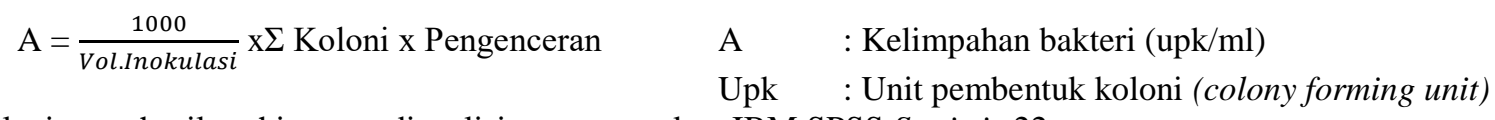

Selanjutnya hasil perhitungan dianalisis menggunakan IBM SPSS Statistic 22. 
Hipotesis yang dapat diambil dalam penelitian ini adalah sebagai berikut :

$\mathrm{H}_{0}$ : Tidak terdapat pengaruh antara kerapatan lamun dengan total kelimpahan bakteri heterotrof

$\mathrm{H}_{1}$ : Terdapat pengaruh antara kerapatan lamun dengan total kelimpahan bakteri heterotrof.

Kaidah pengambilan keputusan adalah sebagai berikut :

Jika $\mathrm{F}$ hitung $>\mathrm{F}$ tabel $(a=0,005)$ maka tolak $\mathrm{H}_{0}$ dan terima $\mathrm{H}_{1}$, sedangkan jika $\mathrm{F}$ hitung $\leq \mathrm{F}$ tabel maka tolak $\mathrm{H}_{1}$ dan terima $\mathrm{H}_{0}$.

\section{HASIL DAN PEMBAHASAN \\ Hasil \\ Gambaran Umum Lokasi Penelitian}

Pantai Prawean terletak di Desa Bandengan, Kecamatan Jepara, Kabupaten Jepara, Jawa Tengah. Secara geografis

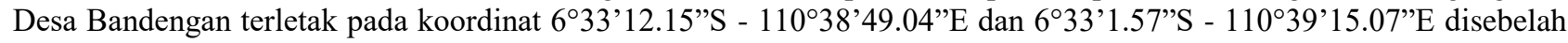
utara Ibukota Kabupaten Jepara. Luas wilayah Desa Bandengan 586,45 Ha dengan garis pantai sepanjang 5 km. Peta lokasi penelitian tersaji dalam gambar 1 sebagai berikut:

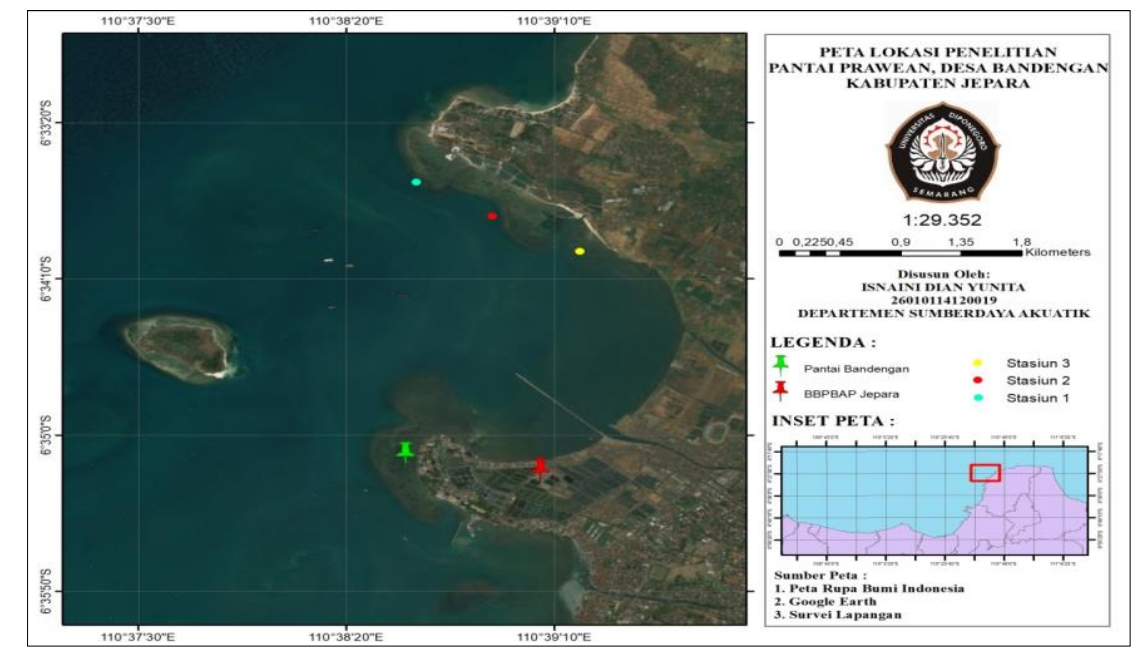

Gambar 1. Peta Lokasi Penelitian

Batas-batas wilayah Desa Bandengan adalah sebagai berikut :

Sebelah utara

Sebelah timur

Sebelah selatan

Sebelah barat

\section{Parameter Fisika dan Kimia}

: Desa Kedungcino dan Desa Mororejo Mlonggo

Parameter fisika diukur secara langsung di lapangan pada pagi hari ketika sedang surut. Berdasarkan Keputusan Menteri Lingkungan Hidup No. 51 tahun 2004, bahwa baku mutu untuk suhu berkisar antara $28-30^{\circ} \mathrm{C}$, salinitas pada ekosistem lamun berkisar antara 33-34\%, nilai DO yakni $>5 \mathrm{mg} / \mathrm{L}$, nilai $\mathrm{pH}$ berkisar antara 7-8,5 nilai nitrat sebesar $0,008 \mathrm{mg} / \mathrm{L}$, dan fosfat sebesar $0,015 \mathrm{mg} / \mathrm{L}$. Hasil rata-rata pengukuran parameter fisika kimia perairan pada lokasi penelitian padang lamun di Pantai Prawean tersaji dalam Tabel 1.

Tabel 1. Parameter Fisika dan Kimia

\begin{tabular}{ccccccc}
\hline Kerapatan & Stasiun & $\begin{array}{c}\text { Kedalaman } \\
(\mathrm{cm})\end{array}$ & $\begin{array}{c}\text { Temperatur } \\
\left({ }^{\circ} \mathrm{C}\right)\end{array}$ & $\begin{array}{c}\text { Salinitas } \\
(\%)\end{array}$ & $\begin{array}{c}\text { DO } \\
(\mathrm{mg} / \mathrm{l})\end{array}$ & $\mathrm{pH}$ \\
\hline \multirow{6}{*}{ Rapat } & 1 & 55 & 29,67 & 30,6 & 6,87 & 7,46 \\
& 2 & 73 & 29,6 & 30,76 & 5,95 & 7,62 \\
& 3 & 46 & 30,15 & 29,73 & 6,25 & 7,68 \\
\cline { 2 - 7 } Sedang & $\dot{\mathrm{x}}$ & 58 & 29,81 & 30,363 & 6,36 & 7,59 \\
\cline { 2 - 7 } & 1 & 58 & 29,6 & 30,76 & 5,95 & 7,62 \\
& 2 & 65 & 29,67 & 30,66 & 5,6 & 7,55 \\
& 3 & 38 & 29,76 & 30,65 & 5,45 & 7,5 \\
\cline { 2 - 7 } Jarang & $\dot{\mathrm{x}}$ & 53,7 & 29,68 & 30,69 & 5,67 & 7,56 \\
\hline & 1 & 40 & 30,15 & 29,73 & 6,25 & 7,68 \\
& 2 & 57 & 30,27 & 29,84 & 5,84 & 7,56 \\
& 3 & 30 & 30,45 & 27,78 & 5,67 & 7,54 \\
\hline
\end{tabular}


Lanjutan Tabel 1. Parameter Fisika dan Kimia

\begin{tabular}{ccc}
\hline Stasiun & Nitrat $(\mathrm{mg} / \mathrm{L})$ & Fosphat $(\mathrm{mg} / \mathrm{L})$ \\
\hline 1 & 0.831 & 0.040 \\
2 & 0.797 & 0.013 \\
3 & 0.866 & 0.020 \\
\hline
\end{tabular}

\section{Tekstur Sedimen}

Berdasarkan pengukuran tekstur sedimen yang telah dilakukan pada masing-masing stasiun pada kerapatan yang berbeda, mayoritas lamun di kawasan Pantai Prawean, tumbuh pada tekstur sedimen pasir (sand) dengan kisaran presentase pasir (sand) 81,55 - 93,46\% dan lumpur (silt) berkisar 6,54-18,45\%. Hasil pengukuran tekstur sedimen pada lokasi penelitian di padang lamun Pantai Prawean, tersaji dalam Tabel 2.

Tabel 2. Tekstur Sedimen

\begin{tabular}{ccccc}
\hline \multirow{2}{*}{ Kerapatan } & \multirow{2}{*}{ Stasiun } & \multicolumn{2}{c}{ Presentase Tekstur Sedimen $(\%)$} & \multirow{2}{*}{ Tekstur Sedimen } \\
\cline { 2 - 4 } & & Sand & Silt & \\
\hline \multirow{3}{*}{ Rapat } & 1 & 82,73 & 17,27 & Pasir Berlempung \\
& 2 & 88,07 & 11,93 & Pasir \\
& 3 & 89,47 & 10,53 & Pasir \\
\cline { 2 - 4 } & $\dot{\mathrm{x}}$ & 86,76 & 13,24 & Pasir \\
\cline { 2 - 4 } Sedang & 1 & 81,55 & 18,45 & Pasir Berlempung \\
& 2 & 93,46 & 6,54 & Pasir \\
& 3 & 89,25 & 10,75 & Pasir \\
\cline { 2 - 4 } & $\dot{\mathrm{x}}$ & 88,09 & 11,91 & Pasir \\
\cline { 2 - 4 } Jarang & 1 & 92,13 & 7,87 & Pasir \\
& 2 & 86,24 & 13,76 & Pasir \\
& 3 & 91,58 & 8,42 & Pasir \\
\hline
\end{tabular}

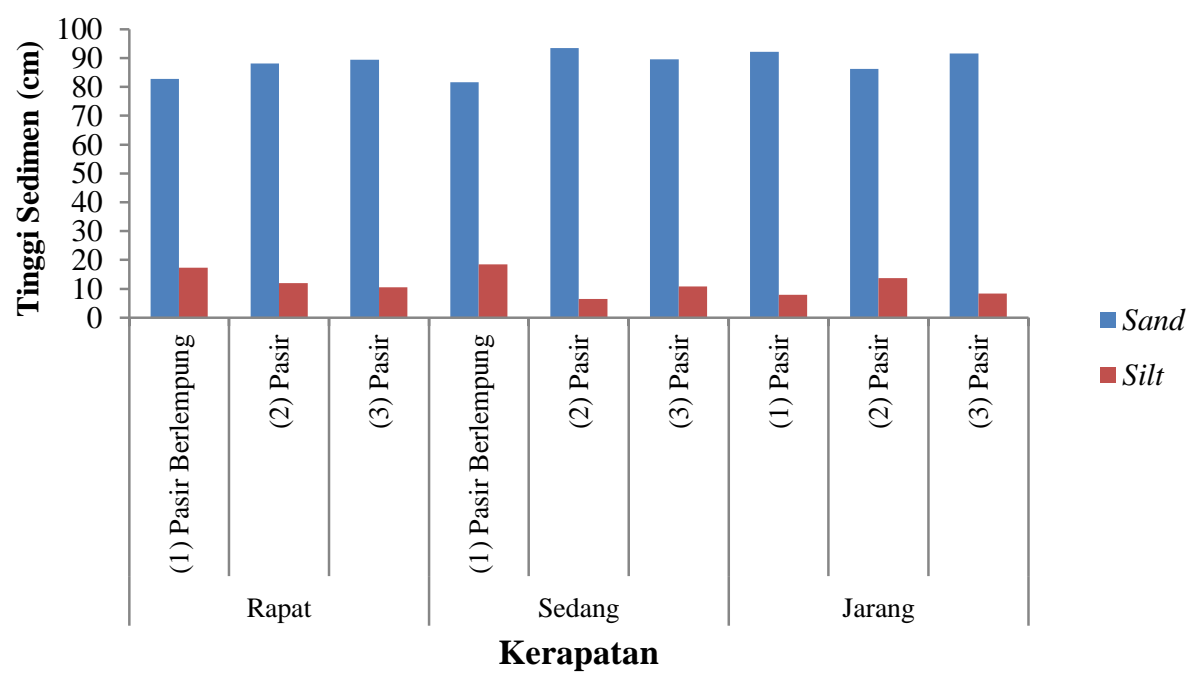

Gambar 2. Diagram Tekstur Sedimen

\section{Kerapatan Lamun}

Berdasarkan perhitungan kerapatan lamun yang telah dilakukan, jenis lamun yang memiliki jumlah tegakan tertinggi adalah jenis Thalassia hemprichii kemudian diikuti oleh Halodule uninervis, Cymodocea rotundata, Halodule pinifolia, dan jenis lamun dengan tegakan terendah diperoleh dari Enhalus acoroides. Hasil perhitungan kerapatan lamun pada lokasi penelitian padang lamun di Pantai Prawean, tersaji dalam Tabel 3,4 Diagram 3,4.

Tabel 3. Kerapatan Lamun

\begin{tabular}{|c|c|c|c|c|c|c|c|}
\hline \multirow{2}{*}{ Kerapatan } & \multirow{2}{*}{ Stasiun } & \multicolumn{5}{|c|}{ Jenis Lamun $\left(\mathrm{Ind} / \mathrm{m}^{2}\right)$} & \multirow{2}{*}{$\begin{array}{c}\text { Total } \\
\left(\mathrm{Ind} / \mathrm{m}^{2}\right)\end{array}$} \\
\hline & & $\mathrm{Ea}$ & $\mathrm{Th}$ & $\mathrm{Hu}$ & $\mathrm{Hp}$ & $\mathrm{Cr}$ & \\
\hline & 1 & - & 145 & - & - & 264 & 409 \\
\hline \multirow[t]{2}{*}{ Rapat } & 2 & 15 & 251 & - & - & 117 & 383 \\
\hline & 3 & - & - & 616 & - & - & 616 \\
\hline Sedang & 1 & 66 & 142 & - & - & - & 208 \\
\hline
\end{tabular}




\begin{tabular}{|c|c|c|c|c|c|c|c|}
\hline & 2 & - & - & 79 & - & 122 & 201 \\
\hline & 3 & - & 96 & - & 160 & - & 256 \\
\hline & 1 & 8 & 27 & - & - & - & 35 \\
\hline \multirow{2}{*}{ Jarang } & 2 & - & 5 & - & - & 34 & 39 \\
\hline & 3 & - & 37 & - & - & - & 37 \\
\hline \multicolumn{2}{|c|}{ Total } & 89 & 703 & 695 & 160 & 537 & 2184 \\
\hline
\end{tabular}

Tabel 4. Kerapatan Jenis dan Kerapatan Relatif Lamun

\begin{tabular}{lccc}
\hline \multicolumn{1}{c}{ Jenis } & $\begin{array}{c}\text { Jumlah } \\
\text { (Tegakan) }\end{array}$ & $\mathrm{Kj}\left(\mathrm{Ind} / \mathrm{m}^{2}\right)$ & $\mathrm{Kr}(\%)$ \\
\hline Enhalus acoroides & 89 & 10 & $4 \%$ \\
Thalassia hemprichii & 703 & 78 & $32 \%$ \\
Halodule uninervis & 695 & 77 & $32 \%$ \\
Halodule pinifolia & 160 & 18 & $7 \%$ \\
Cymodocea rotundata & 537 & 60 & $25 \%$ \\
\hline TOTAL & & 243 & $100 \%$ \\
\hline
\end{tabular}

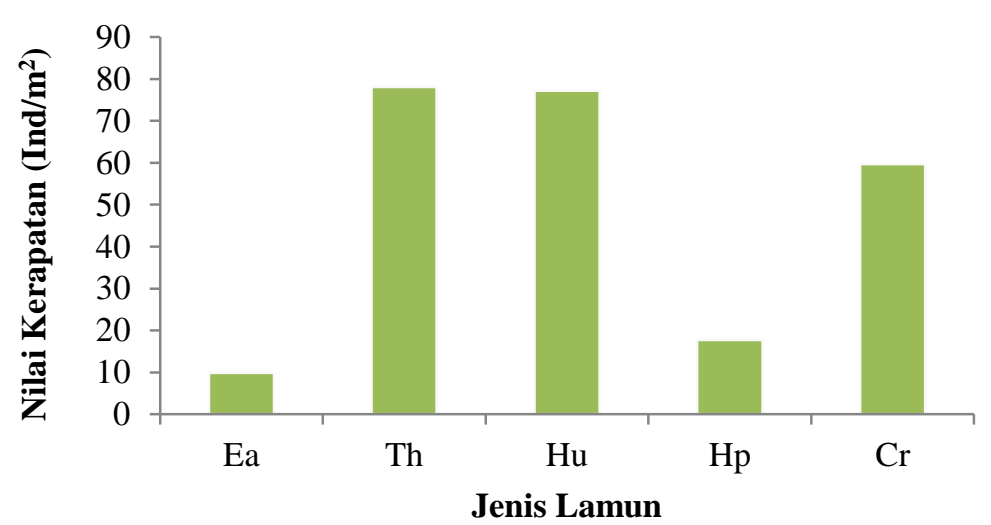

Gambar 3. Diagram Kerapatan Jenis Lamun

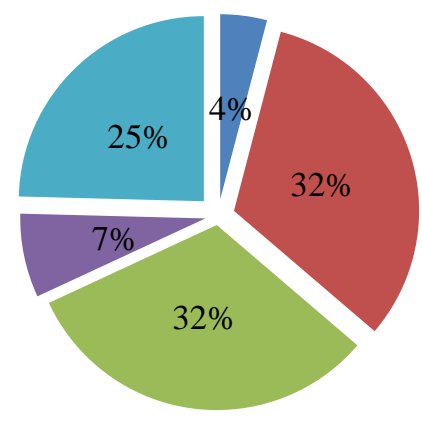

Enhalus acoroides
- Thalassia hemprichii
- Halodule uninervis
$\square$ Halodule pinifolia
$\square$ Cymodocea rotundata

Gambar 4. Diagram Kerapatan Relatif Lamun

\section{Kelimpahan Bakteri Heterotrof}

Berdasarkan hasil penanaman bakteri heterotrof pada media TGY (Triptone Glucose Yeast) yang telah dilakukan pada tingkat pengenceran $3\left(10^{3}\right)$. Jenis lamun yang dipilih untuk ditanam pada media adalah Thalassia hemprichii karena jenis T.hemprichii inilah yang memiliki nilai kerapatan yang paling tinggi dan dapat ditemui pada semua stasiun pengamatan. Hasil perhitungan total kelimpahan bakteri heterotrof pada lokasi penelitian di padang lamun Pantai Prawean, tersaji dalam Tabel 5.

Tabel 5. Kelimpahan Bakteri Heterotrof

\begin{tabular}{cc}
\hline \multirow{2}{*}{ Kerapatan } & Total Bakteri $\times 10^{3}(\mathrm{Upk} / \mathrm{ml})$ \\
\cline { 2 - 2 } & Stasiun \\
\hline
\end{tabular}




\begin{tabular}{ccccc}
\hline & 1 & 2 & 3 & $\dot{\mathrm{x}}$ \\
\hline Rapat & $27,2 \times 10^{8}$ & $24,6 \times 10^{8}$ & $29,4 \times 10^{8}$ & $27,1 \times 10^{8}$ \\
Sedang & $13,2 \times 10^{8}$ & $10,7 \times 10^{8}$ & $16,8 \times 10^{8}$ & $13,6 \times 10^{8}$ \\
Jarang & $7,8 \times 10^{8}$ & $3,3 \times 10^{8}$ & $15,6 \times 10^{8}$ & $8,9 \times 10^{8}$ \\
\hline
\end{tabular}

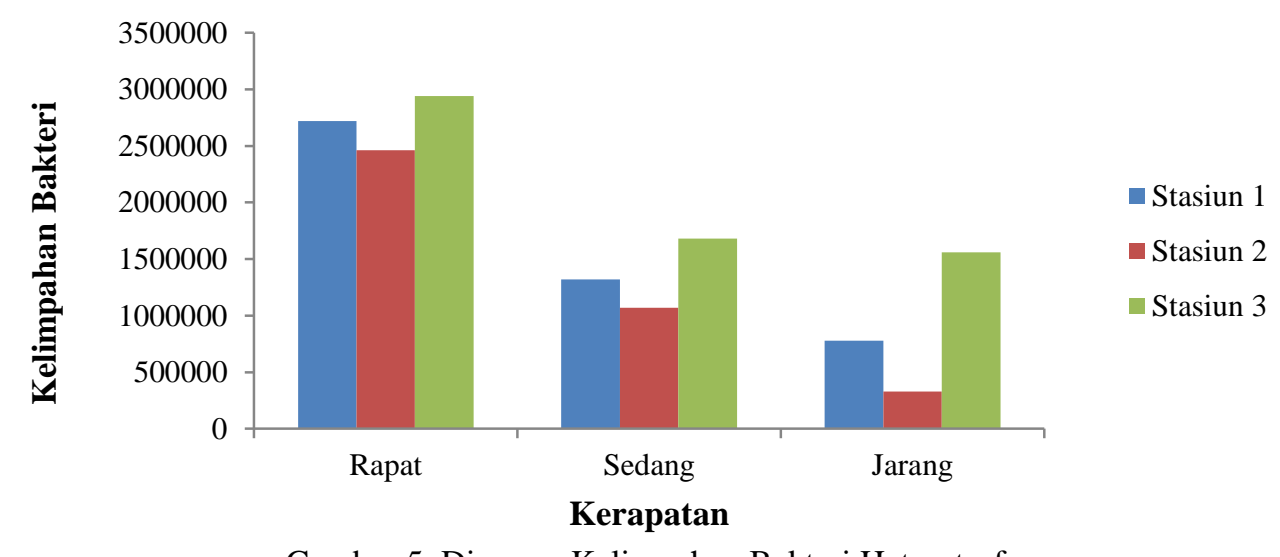

Gambar 5. Diagram Kelimpahan Bakteri Heterotrof

\section{Pembahasan \\ Parameter Fisika dan Kimia Ekosistem Lamun}

Berdasarkan hasil pada pengukuran parameter fisika dan kimia yang didapatkan diperoleh kedalaman perairan berkisar $30-73 \mathrm{~cm}$. Jarak lokasi stasiun 1 dengan pantai yakni $50 \mathrm{~m}$, sedangkan jarak antar stasiun 1 dengan stasiun lainnya $\pm 100 \mathrm{~m}$. Pengukuran parameter fisika dan kimia dilakukan pada pagi hari, ketika sedang surut sehingga perhitungan kerapatan lamun mudah untuk dilakukan. Kedalaman dan kecerahan perairan juga mempengaruhi distribusi bakteri heterotrof. Pada perairan dangkal (neritik) dengan cukup cahaya, umumnya kelimpahan fitoplankton dan bakteri heterotrof lebih tinggi. Hal ini diperkuat oleh Notowinarto (2015) bahwa pada zona litoral dan sublitoral perairan umumnya kandungan bakteri heterotrofik lebih tinggi dan jenisnya lebih banyak bila dibandingkan dengan zone abyssal atau hadal.

Nilai temperatur air yang diperoleh pada saat penelitian yakni berkisar antara $29,6-30,45^{\circ} \mathrm{C}$. Temperatur ini sangat sesuai untuk pertumbuhan lamun, karena sesuai dengan baku mutu air laut untuk biota laut yang ditetapkan pada Keputusan Menteri Lingkungan Hidup No.51 tahun 2004 bahwa kisaran suhu yang optimium untuk ekosistem lamun yakni $28-30^{\circ} \mathrm{C}$. Menurut Dahuri (2003) kemampuan fotosintesis akan menurun dengan tajam apabila temperatur perairan berada di luar kisaran optimal.

Nilai salinitas pada lokasi penelitian berkisar antara 27,78-30,76\%. Masing-masing spesies lamun memiliki kisaran toleransi salinitas yang berbeda-beda. Baku mutu salinitas untuk ekosistem lamun menurut Keputusan Menteri Lingkungan Hidup No. 51 tahun 2004 yakni 33-34\%. Hal ini menunjukkan bahwa nilai salinitas di Pantai Prawean Jepara belum memenuhi baku mutu air laut untuk biota laut. Menurut Dahuri, (2003) bahwa spesies lamun mempunyai kemampuan toleransi yang berbeda-beda terhadap salinitas, sebagian besar memiliki kisaran yang lebar, yaitu antara $10-40 \%$. Nilai salinitas optimum untuk spesies lamun $35 \%$.

DO (Dissolved Oxygen) yang diperoleh pada lokasi penelitian yakni berkisar antara 5,03-6,87 mg/L. Berdasarkan KepMen LH No.51 tahun 2004, baku mutu oksigen terlarut bagi biota laut yakni $>5$. Hal ini menunjukkan bahwa oksigen terlarut yang ada di Pantai Prawean telah sesuai dengan baku mutu yang telah ditentukan. Nilai ini tidak jauh berbeda dengan penelitian Finishia et al. (2014) bahwa nilai DO pada ekosistem lamun di Pantai Prawean yang diperoleh yakni 5,42-6,01 mg/L.

Nilai pH yang diperoleh pada penelitian yakni berkisar antara 7,46-7,68. Nilai ini sudah sesuai dengan baku mutu untuk biota laut yang ditetapkan pada KepMen LH No.51 tahun 2004. Menurut Hidayah et al. (2016) derajat keasaman $(\mathrm{pH})$ perairan yang baik untuk pertumbuhan organisme air berkisar antara 6,5-8,5. Secara keseluruhan nilai $\mathrm{pH}$ perairan rendah mendekati pesisir dan cenderung meningkat mendekati perairan laut.

Rata-rata nilai nitrat pada Pantai Prawean yakni $0,831 \mathrm{mg} / \mathrm{L}$ dan fosfat $0,024 \mathrm{mg} / \mathrm{L}$. Nilai nitrat dan fosfat tertinggi diperoleh dari stasiun 1 dan 3, dan nilai terendah diperoleh dari stasiun 2. Menurut KepMen LH No.51 tahun 2004, hasil pengukuran nitrat dan fosfat di Pantai Prawean telah melebihi baku mutu untuk biota laut. Hal ini menunjukkan bahwa kandungan nutrien di Pantai Prawean Jepara sangat tinggi.

\section{Tekstur Sedimen Ekosistem Lamun}

Pantai Prawean, Jepara merupakan pantai yang mendukung untuk pertumbuhan lamun, karena memiliki kelandaian dengan tekstur sedimen berupa sedimen berpasir, berlumpur, dan pecahan karang. Lamun merupakan 
tumbuhan dangkal yang dapat tumbuh pada berbagai jenis tekstur sedimen. Tekstur sedimen yang diperoleh di pantai Prawean yakni pasir dan pasir berlempung. Selama pengamatan, lamun yang ditemui pada tektur sedimen pasir halus adalah jenis Thalassia hemprichii, Halodule uninervis, dan Halodule pinifolia, pada tekstur pasir kasar dapat ditemui jenis Thalassia hemprichii dan Enhalus'acoroides, sedangkan pada tekstur sedimen pasir berlempung, jenis lamun yang ditemui yakni Cymodocea rotundata, Thalassia hemprichii, dan Enhalus acoroides. Hasil pengamatan menunjukkan bahwa jenis lamun yang dapat beradabtasi pada semua jenis substrat adalah jenis Thalassia hemprichii. Hal ini diperkuat oleh Romimohtarto dan Juwana (2001) dalam Suryanti et al. (2014) bahwa Thalassia hemprichii memiliki strategi adabtasi yang baik terhadap lingkungannya dimana tumbuhan tersebut memiliki perakaran serabut yang mampu berkoloni lebih lebat di habitat dangkal dibandingkan jenis lamun lainnya.

\section{Kerapatan Lamun}

Berdasarkan pengamatan, kondisi padang lamun di Pantai Prawean, Jepara tergolong cukup bagus dan relatif subur, dapat dilihat dari kerapatan dan keanekaragaman yang ada. Lamun yang ditemui selama penelitian terdiri dari 5 jenis antara lain : Enhalus acoroides, Thalassia hemprichii, Halodule uninervis, Halodule pinifolia dan Cymodocea rotundata. Total tegakan tertinggi diperoleh dari jenis Thalassia hemprichii yakni sebanyak $703 \mathrm{Ind} / \mathrm{m}^{2}$, dengan nilai kerapatan jenis $78 \mathrm{Ind} / \mathrm{m}^{2}$ dan kerapatan relatif $32 \%$ sehingga menurut Brauns-Blanquet, (1965) masuk dalam skala 3 (agak rapat), kemudian disusul oleh Halodule uninervis dengan jumlah total tegakan sebanyak $695 \mathrm{Ind} / \mathrm{m}^{2}$ dan nilai kerapatan jenis $77 \mathrm{Ind} / \mathrm{m}^{2}$ serta kerapatan relatif $32 \%$ dan masuk dalam skala 3 (agak rapat), Cymodocea rotundata diperoleh jumlah total tegakan sebanyak $537 \mathrm{Ind} / \mathrm{m}^{2}$ dengan nilai kerapatan jenis $60 \mathrm{Ind} / \mathrm{m}^{2}$ dan kerapatan relatif $25 \%$, Halodule pinifolia diperoleh jumlah tegakan sebanyak $160 \mathrm{Ind} / \mathrm{m}^{2}$ dengan nilai kerapatan jenis $18 \mathrm{Ind} / \mathrm{m}^{2}$ dan kerapatan relatif $7 \%$ serta Enhalus acoroides diperoleh jumlah total tegakan sebanyak $89 \mathrm{Ind} / \mathrm{m}^{2}$ dengan kerapatan jenis 10 $\mathrm{Ind} / \mathrm{m}^{2}$ dan kerapatan relatif $4 \%$ sehingga Cymodocea rotundata, Halodule pinifolia, dan Enhalus acoroides masuk dalam skala 2 (jarang).

\section{Kelimpahan Bakteri Heterotrof}

Lamun jenis Thalassia hemprichii dipilih sebagai isolat untuk ditanam pada media, dikarenakan keberadaannya yang dapat ditemui pada semua stasiun dan kelimpahannya paling tinggi. Pengenceran yang digunakan dalam penanaman bakteri heterotrof yakni pengenceran $10^{3}$, karena pada pengenceran $10^{3}$, total bakteri yang tumbuh sudah memenuhi syarat standar plate count (SPC) yakni terdapat bakteri antara 30-300 pada tiap cawannya.

Rata-rata total kelimpahan bakteri tertinggi diperoleh dari ekosistem lamun di stasiun 3 yakni sebanyak $29,4 \times 10^{8}$ $\mathrm{Upk} / \mathrm{ml}$ pada stasiun rapat, $16,8 \times 10^{8} \mathrm{Upk} / \mathrm{ml}$ pada stasiun sedang, dan $15,6 \times 10^{8} \mathrm{Upk} / \mathrm{ml}$ pada stasiun jarang. Kemudian stasiun 1 dengan jumlah total bakteri sebanyak $27,2 \times 10^{8} \mathrm{Upk} / \mathrm{ml}$ pada stasiun rapat, $13,2 \times 10^{8} \mathrm{Upk} / \mathrm{ml}$ pada stasiun sedang, dan $7,8 \times 10^{8} \mathrm{Upk} / \mathrm{ml}$ pada stasiun jarang, dan rata-rata terendah diperoleh dari stasiun 2 dengan jumlah total bakteri sebanyak $24,6 \times 10^{8} \mathrm{Upk} / \mathrm{ml}$ pada stasiun rapat, $10,7 \times 10^{8} \mathrm{Upk} / \mathrm{ml}$ pada stasiun sedang, dan $3,3 \times 10^{8} \mathrm{Upk} / \mathrm{ml}$ pada stasiun jarang. Hal ini menunjukan bahwa pada tingkat kerapatan rapat kelimpahan bakteri heterotrof jumlahnya melimpah atau tinggi dan semakin berkurang jumlahnya pada tingkat kerapatan sedang dan jarang, sehingga dapat dikatakan bahwa kerapatan lamun berbanding lurus dengan kelimpahan bakteri heterotrof dikarenakan semakin rapat lamun, maka bahan organik yang merupakan makanan dari bakteri heterotrofik untuk melakukan proses dekomposisi cukup banyak dan mengindikasikan bahwa kelimpahan bakteri heterotrof juga tinggi.

\section{Hubungan Kerapatan Lamun dengan Kelimpahan Bakteri Heterotrof}

Berdasarkan analisis data pengaruh kerapatan lamun dengan kelimpahan bakteri heterotrof dengan software IBM SPSS Statistic 22 diperoleh nilai rata-rata kelimpahan bakteri heterotrof sebesar 1651111,11 dengan standar deviasi 895732.165 dan rata-rata kerapatan lamun sebesar 242,67 dengan standar deviasi 198,984. Nilai R sebesar 0,896 menunjukkan terdapat korelasi antara kerapatan lamun dengan kelimpahan bakteri heterotrof. Korelasi antara kerapatan lamun dengan kelimpahan bakteri heterotrof tinggi atau kuat yakni 0,896 dan korelasi ini dinyatakan sangat signifikan terbukti nilai sig. 0,001. Nilai $\mathrm{R}$ Square sebesar 0,802 yang artinya adalah kerapatan lamun mampu memberikan sumbangan pada kelimpahan bakteri heterotrof sebesar 0,802 atau 80,2\% dan sisanya 19,8\% dipengaruhi oleh variabel lain. Nilai F hitung yang diperoleh 28,426 dengan signifikansi 0,001 atau tingkat kesalahan $0,1 \%$. Hal ini menunjukkan bahwa model regresi dapat digunakan untuk membuat estimasi kelimpahan bakteri heterotrof. Persamaan regresi yang diperoleh yakni $\mathrm{Y}=672598,612+4032,332 \mathrm{X}$. Nilai konstanta (constant) sebesar 672598,612 sedangkan nilai koefisien regresi X sebesar 4032,332 artinya bila kerapatan lamun bertambah $1 \mathrm{Ind} / \mathrm{m}^{2}$ maka akan meningkatkan kelimpahan bakteri heterotrof sebesar 4032,332 Upk/ml. Kerapatan lamun memiliki pengaruh yang sangat signifikan terhadap kelimpahan bakteri heterotrof terbukti nilai sig. 0,001 atau tingkat kesalahan 0,1\% karena kerapatan lamun terbukti memiliki pengaruh yang sangat signifikan terhadap kelimpahan bakteri heterotrof, maka model regresi ini dapat digunakan sebagai dasar estimasi perhitungan kelimpahan bakteri heterotrof dan dapat disimpulkan bahwa hipotesis yang diperoleh yakni tolak Ho dan terima H1, sehingga terdapat pengaruh antara kerapatan lamun dengan kelimpahan bakteri heterotrof.

\section{KESIMPULAN DAN SARAN}

\section{Kesimpulan}

Berdasarkan penelitian mengenai Pengaruh Kondisi Lokasi dan Kerapatan Lamun terhadap Kelimpahan Bakteri Heterotrof di Pantai Prawean, Jepara dapat diambil kesimpulan bahwa nilai total kerapatan semua jenis lamun yang 
diperoleh sebanyak 242,67 Ind/m². Kerapatan tertinggi Thalassia hemprichii sebanyak $78 \mathrm{Ind} / \mathrm{m}^{2}$, Halodule uninervis sebanyak $77 \mathrm{Ind} / \mathrm{m}^{2}$ keduanya masuk pada skala 3 (agak rapat), Cymodocea rotundata sebanyak $60 \mathrm{Ind} / \mathrm{m}^{2}$, Halodule pinifolia sebanyak $18 \mathrm{Ind} / \mathrm{m}^{2}$, dan Enhalus acoroides sebanyak $10 \mathrm{Ind} / \mathrm{m}^{2}$ ketiganya masuk pada skala 2 (Jarang). Rata-

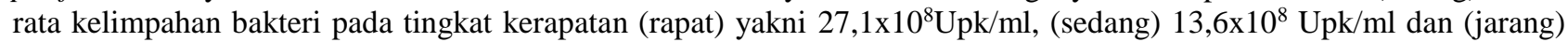
8,9 $10^{8} \mathrm{Upk} / \mathrm{ml}$. Korelasi kerapatan lamun dengan kelimpahan bakteri heterotrof yakni 0,896 korelasi dinyatakan kuat dan sangat signifikan dengan nilai sig. 0,001 atau tingkat kesalahan $0,1 \%$. Kerapatan lamun menyumbang $80,2 \%$ terhadap kelimpahan bakteri heterotrof, sisanya 19,8\% dipengaruhi faktor lain sehingga setiap kerapatan lamun bertambah $1 \mathrm{Ind} / \mathrm{m}^{2}$ maka akan meningkatkan kelimpahan bakteri heterotrof sebesar 4032,332 Upk/ml.

\section{UCAPAN TERIMAKASIH}

Ucapan terimakasih ditujukan kepada Ir. Anhar Solichin, M.Si dan Dr. Ir. Pujiono Wahyu P.,MS yang telah memberikan saran dan kritik yang sangat bermanfaat bagi penulis. Kepada semua pihak yang telah membantu sehingga penulis dapat menyelesaikan artikel ini.

\section{DAFTAR PUSTAKA}

Aminulloh, F. 2011. Analisis Bahan Organik dan Nitrogen Total pada Sistem Budidaya Ikan pada Skala Laboratorium. Bogor: Program Keahlian Analisis Kimia IPB.

Ariyanti, V.N., Supriharyono, dan N. Widyorini. 2016. Hubungan Kerapatan Lamun dengan Kelimpahan Bakteri Heterotrof di Perairan Pantai Kartini Kabupaten Jepara. Journal of Maquares. 5(4): 142-149.

Brauns-Blanquet, J. 1965. Plant Sociology: The Study of Plant Communities, (Trans rev and ed by C.D. Fuller and H.S. Conard). Harner, London.

Dahuri, R. 2003. Keanekaragaman Hayati Laut: Aset Pembangunan Berkelanjutan Indonesia. Jakarta: Gramedia Pustaka Utama.

Febriyantoro, I. Riniatsih, dan H. Endrawati. 2013. Rekayasa Teknologi Transplantasi Lamun (Enhalus acoroides) di Kawasan Padang Lamun Perairan Prawean, Bandengan Jepara. Jurnal Penelitian Kelautan. 1(1): 1-10.

Finishia, T., I. Riniatsih, dan H.Endrawati. 2014. Struktur Komunitas Polychaeta pada Ekosistem Padang Lamun Alami dan Buatan di Perairan Pantai Prawean Bandengan, Jepara. Journal of Marine Research. 3(4): 483-491.

Hafsan., E. Sukmawati dan M. Masri. 2015. Penuntun Praktikum Mikrobiologi. Laboratorium Mikrobiologi Fakultas Sains dan Teknologi Universitas Islam Negeri Alauddin, Makassar.

Hidayah, G., S.Y.Wulandari dan M. Zainuri. 2016. Studi Sebaran Klorofil-a Secara Horizontal di Perairan Muara Sungai Silugonggo Kecamatan Batangan, Pati. Buletin Oseanografi Marina. 5(1): 52-59.

Kementerian Lingkungan Hidup. 2004. Keputusan Menteri Lingkungan Hidup No. 51/2004 tentang Baku Mutu Air Laut untuk Biota Laut. Kementerian Lingkungan Hidup Republik Indonesia, Jakarta.

Notowinarto dan F. Agustina. 2015. Populasi Bakteri Heterotrof di Perairan Pulau Bulang Batam. Jurnal Pendidikan Biologi Indonesia. 1(3): 334-342.

Prita, A.W., I. Riniatsih dan R. Ario. 2014. Struktur Komunitas Fitoplankton pada Ekosistem Padang Lamun di Perairan Pantai Prawean Bandengan, Jepara. Journal of Marine Research. 3(3): 380-387.

Suryanti, C. A'in, Tishmawati, C.N. 2014. Hubungan Keerapatan Lamun (Seagrass) dengan Kelimpahan Sygnathidae di Pulau Panggang Kepulauan Seribu. Diponegoro Journal of Maquares. 3(4): 147-153. 